\title{
Prospective Trends in Neuromarketing Tools of the Food Industry in View of Ukrainian Society Digitalization
}

\author{
Tatiana Zubko, Iryna Kovshova, Oksana Sydorenko
}

\begin{abstract}
The objective of this study was to explore theoretical and methodological provisions for implementation of neuromarketing tools within food companies to define the main needs and wishes of young people. The respondents were interviewed to analyze their emotional, rational and behavioral responses, which occur when they buy foodstuffs. The authors have developed the motivational model of effect of neuromarketing stimuli on the food industry and society. It was defined that as a result of society digitalization, the Ukrainian youth have emotional, rational and behavioral responses, which are different from those of the older consumer audience. Scientific novelty of the study results laid in development of a motivational model of applying neuromarketing stimuli for food companies' effect on a society.
\end{abstract}

Key words: neuromarketing tools, society digitalization, motivational model, foodstuffs, neuromarketing stimuli, emotional, rational and behavioral responses.

\section{INTRODUCTION}

Over the recent years, neuromarketing has become the most innovative direction in the study of consumer behavior in the Western Europe and the USA and the main tool of impact on the business environment. In the Ukrainian food industry has arisen a trend of gradual changes in behavioral preferences of the millennial consumers: steadily growing needs in ecological and natural foodstuffs in the light of market globalization, permanently rising effect of digitalization on emotional, rational and behavioral responses. Thus, neuromarketing tools form the grounds for more thoroughly research of true consumer reactions and are the source of relevant data for revealing peculiarities of formation of consumer preferences in foodstuffs among the Ukrainian youth aged 16 to 23 years old to define effective measures of attracting their attention and popularization of food companies in this segment of buyers.

Managerial stuff of food companies can use neuromarketing tools at different stages of food consumer monitoring: while planning the assortment policy, arranging sales promotion, attracting attention to particular attributes of foodstuffs, motivating potential consumers to increase the coverage level (the number of real household consumers) and penetration

Revised Version Manuscript Received on October 15, 2019.

PhD Zubko Tatyana, Associate Professor, Department of Economics and Finance, Kyiv National University of Trade and Economics, Kyiv, Ukraine. (Email: zubkotl@gmail.cO)

Dr. Iryna Kovshova, Professor, Department of marketing and business management, National University "Kyiv-Mohyla academy", Kyiv, Ukraine. (Email: iryna.kovshova@ukma.edu.ua)

Dr. Oksana Sydorenko, Professor, Department of marketing and

business management, National University "Kyiv-Mohyla academy", Kyiv, Ukraine. (Email: o.sydorenko@ukma.edu.ua) (sales volumes bought by an individual household). The main obstacle for implementing neuromarketing tools by food companies is a need in digitization of processes, availability of special equipment and additional financing of specialists who decrypt and interpret results of such researches.

\section{LITERATURE REVIEW}

The theoretical and applied provisions of using the effect of neuromarketing tools on the business environment are partially presented in scientific works and monographs of the following researchers: Arieli D. and Berns G. S. [3], Banks S. J., Bellerose J., Douglas D. and Jones-Gotman M. [4], Kovshova I. [1], Dhananjay M. and Milind M. [5], Oklander M. and Hubareva Y. [2], Harrel E. [6], McClure S. M. and Tomlin D. [8], Fortunato V. C. R., Giraldi J. D. M. E. and Oliveira J. H. C. [7] etc. However, the absence of universal neuromarketing models grounding on the principles and patterns of brain reactions is becoming more and more actual and determines the urgency of this research.

\section{PURPOSE OF THE STUDY}

The goal of this article is the development of theoretical and methodological provisions and practical recommendations for implementation of neuromarketing tools within food companies to define the main emotional, rational and behavioral responses of millennials and to form new consumer preferences taking into account the society digitization factor.

\section{METHODOLOGIE}

Theoretical and methodological basis of the research has formed the concepts of the modern socio-economic theory, neuromarketing and behavioral economy. The research is grounded on the dialectic method of studying the effect of neuromarketing tools on the food industry. Within the framework of this approach, general scientific and specific methods have been used, in particular: comparison - to determine the advantages and disadvantages of different groups of neuromarketing tools; a survey - to carry out a pilot research of emotional, rational and behavioral responses of millennials when buying foodstuffs; mathematical modeling - to evaluate the data obtained during the experiment and to define the Ukrainian society digitization trends; analysis and 
synthesis - to create a mechanism for implementation of neuromarketing tools in food companies; induction and deduction - to make conclusions based on the study results.

\section{FINDINGS AND DISCUSSION}

Nowadays the managerial stuff of food companies mainly uses rational arguments to increase the awareness of the interested parties (consumers, intermediaries, partners, investors etc.) regarding foodstuffs.

The main hypotheses of the rational approach to the effect on a society are as follows:

- before to make a decision whether to buy foodstuffs a consumer looks for information and carries out an independent research keeping in mind and comparing the available data on different alternatives;

- the intermediaries rationally determine needs and wishes by choosing the most advantageous offer based on the price and quality correlation;

- the managerial stuff of food companies has to use rational and logical arguments to create a loyalty of intermediaries, partners, investors and consumers [1].

In this approach the available tools are incomplete due to the absence of the emotional component, which is now becoming more and more significant for the millennial consumers who are gradually increasing their presence at the food market.

At the same time the use of rational and emotional marketing tools in combination with digitization allows promoting particular foodstuffs of a definite food company or industry among the young generation. Specific features of the effect of rational and emotional marketing tools on consumer preferences of millennials are demonstrated in figure 1 .

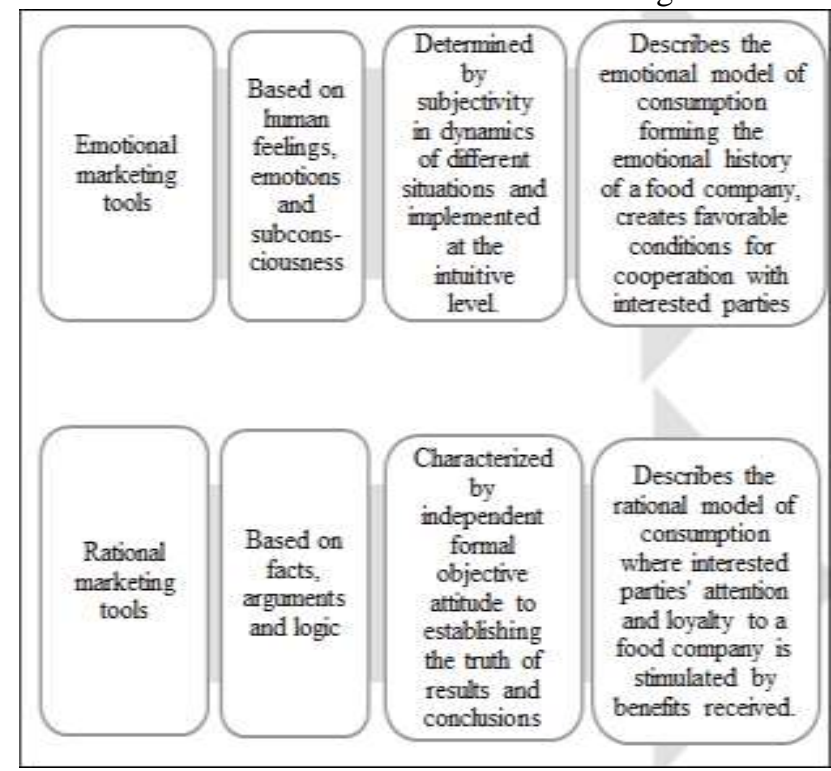

Fig. 1. Specific features of the effect of rational and emotional marketing tools on the formation of millennial consumer benefits

During the research it was assumed that as a result of society digitalization, millennials - the young people aged 16 to 23 years old who were born at the border of the century (from 1997 to 2003) - have other emotional, rational and behavioral responses when buying foodstuffs, unlike the older consumer audience. The Internet expansion, availability of smartphones (gadgets), development of specialized CRM systems, consumer application software and programs, the impact of information and marketing technologies have contributed to emergence of a new group of consumers having specific expectations for foodstuffs according to their lifestyle. Despite the fact that millennials are interested in the same basic function of foodstuffs (quenching hunger and thirst), got some similar characteristics of rational and behavioral responses, but have specific emotional expectations for the same products or services. So, there is a need in performing an additional research and dividing millennials into subgroups with homogeneous similar characteristics in order to study their responses to particular foodstuffs and create a basic typology.

To confirm the basic hypothesis, a pilot study of consumer preferences was carried out among millennial students living in Kyiv and studying at the National University of Kyiv-Mohyla Academy and the Kiev National University of Trade and Economics.

For the analysis of emotional, rational and behavioral responses of young people when buying foodstuffs, 310 respondents were interviewed. This survey consisted of more than 50 questions combined into three blocks. Summarized data on millennials' responses to the nutrition habits, decisions on buying foodstuffs and marketing impact of food companies are presented in figure 2 .

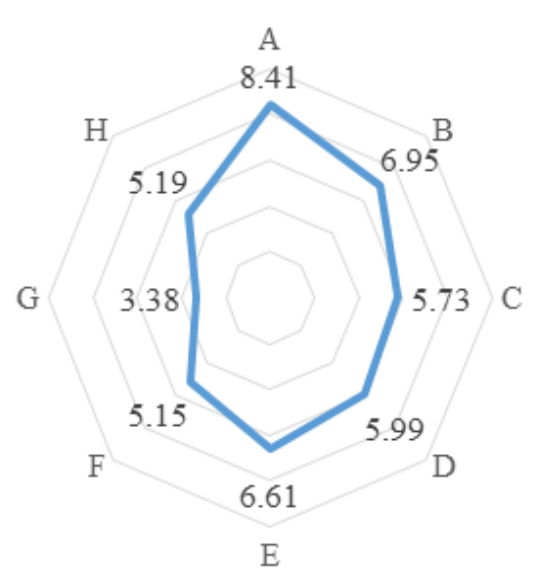

A - "Implementation of ideas of healthy nutrition and lifestyle is a need of today";

B - "I prefer healthy food";

C - "Leaving a healthy life is following a fashion";

D - "Promoting the use of natural foodstuffs is a marketing tool of food companies";

E - "I agree to pay a higher price for organic food";

F - "I prefer novelties in the range of foodstuffs";

$\mathrm{G}$ - "Advertisement has an impact on my decisions which foodstuffs to buy";

$\mathrm{H}$ - "When choosing foodstuffs, I follow my friends' advices".

Fig. 2. Emotional, rational and behavioral responses of the Ukrainian millennials when buying foodstuffs (the pilot study results) 
The respondents were proposed to estimate the eight basic statements characterizing their perception according to a scale: 0 points - absolutely disagree with a statement; 2.5 points - rather disagree; 5 points - difficult to determine (neutral); 7.5 points - rather agree with a statement; 10 points - absolutely agree.

Among the Ukrainian millennials living in cities, the highest value was received for statement "A" referring to imitation of ideas of healthy nutrition and lifestyle (8.41 of 10 points). The lowest value was received for statement " $\mathrm{G}$ " referring to a low impact of advertisement on a decision to buy a foodstuff (3.38 of 10 points). As well, was fixed an almost neutral value referring to millennials' perception of novelties in a range of foodstuffs (5.15 points) and their perception of friends' advices (5.19 points).

Additional studies enabled to define the degree of ties between the level of students' monthly income (a quantitative characteristic) and the way of foodstuff selection (a psychological qualitative characteristic). To define the interrelation between above mentioned characteristics was use correlation method based on prognostic models with calculating of three Guttman coefficients. Two of the coefficients are directional, i.e. a possibility to define the ability to predict one characteristic grounded on the data of the other characteristic. At the same time, we must admit, that this measure does not give you any information on the ability to make reverse prediction. The third coefficient is averaging of the two previous ones. The model of conjugation of a psychological qualitative characteristic (of choosing a foodstuff $(\mathrm{X})$ ) and a quantitative characteristic (of student income level (Y)) is presented in table 1 .

Table 1: model of conjugation of psychological characteristics of choosing foodstuffs $(X)$ and income levels of the Ukrainian millennial students (Y) (results of a pilot survey of 310 respondents)

\begin{tabular}{|c|c|c|c|c|c|}
\hline \multirow{2}{*}{$\begin{array}{l}\text { Monthly } \\
\text { income, } \\
\text { hrn }\end{array}$} & \multicolumn{3}{|c|}{$\begin{array}{l}\text { Characteristic of } \\
\text { choosing foodstuffs }\end{array}$} & \multirow{2}{*}{$\begin{array}{l}\text { Total } \\
\text { number of } \\
\text { responden } \\
\text { ts }\end{array}$} & \multirow{2}{*}{$\begin{array}{l}\text { Maximu } \\
\mathrm{m} \\
\text { frequency }\end{array}$} \\
\hline & $\begin{array}{c}\text { intui } \\
\text { tivel } \\
\mathrm{y}\end{array}$ & $\begin{array}{l}\text { pragm } \\
\text { aticall } \\
y\end{array}$ & $\begin{array}{l}\text { situa } \\
\text { tion } \\
\text { ally }\end{array}$ & & \\
\hline$<2000$ & 5 & 64 & 57 & 126 & 64 \\
\hline $\begin{array}{c}2000-500 \\
0\end{array}$ & 3 & 54 & 40 & 97 & 54 \\
\hline $\begin{array}{c}5000-100 \\
00 \\
\end{array}$ & 8 & 20 & 29 & 57 & 29 \\
\hline$>10000$ & 5 & 16 & 9 & 30 & 16 \\
\hline Total & 21 & 154 & 135 & 310 & 163 \\
\hline $\begin{array}{l}\text { Maximum } \\
\text { frequency }\end{array}$ & 8 & 64 & 57 & 129 & \\
\hline
\end{tabular}

According to the data demonstrated in the table Guttman coefficients were calculated:

$$
\begin{gathered}
\lambda_{y x}=\frac{\sum_{i} \max _{j} n_{i j}-\max _{i} \sum_{j} n_{i j}}{n-\max _{i} \sum_{j} n_{i j}} \\
=\frac{(64+54+29+16)-\max \{21 ; 154 ; 135\}}{310-\max \{21 ; 154 ; 135\}}= \\
=\frac{163-154}{310-154}=\frac{9}{156} \approx 0,0577
\end{gathered}
$$

$$
\begin{gathered}
\lambda_{x y}=\frac{\sum_{j} \max _{i} n_{i j}-\max _{j} \sum_{j} n_{i j}}{n-\max _{j} \sum_{i} n_{i j}} \\
=\frac{(8+64+57)-\max \{126 ; 97 ; 53 ; 30\}}{310-\max \{126 ; 97 ; 53 ; 30\}}= \\
=\frac{129-126}{310-126}=\frac{3}{184} \approx 0,0163
\end{gathered}
$$

Taking into consideration that one of the characteristics refer to psychological aspects of selecting actions, a corrected correlation coefficient was calculated:

$$
\lambda=\frac{\lambda_{y x}+\lambda_{x y}}{2}=\frac{0,0577+0,0163}{2} \approx 0,037
$$

Based on the conjugation model was revealed a significant correlation between the amount of monthly income of respondents and psychological features of choosing foodstuffs. So, the students of the first two groups with an income up to 5000 hryvnas make decisions pragmatically comparing price and quality. Simultaneously, in the third and fourth group of students with an income of more than 5000 hryvnas can be observed a tendency to situational choice depending on definite circumstances and mood. The further studies allowed to conclude that the students of the $3^{\text {rd }}$ and $4^{\text {th }}$ groups most often combine studies and work that cause the occurrence of an additional parameter of choosing foodstuffs: comparison of available budget and the time spent on a purchase.

Based on criteria $\chi^{2}$ was evaluated the degree of tightness of interrelation between the characteristics studied. If $\chi^{2}>$ table $\chi^{2}$, at given $(\alpha ;(m-1) ;(n-1))$, than the statistic interrelation between variables $\mathrm{X}$ and $\mathrm{Y}$ with probability $(1-\alpha) \cdot 100 \%$ exists, if all cells of the conjugation table are completed.

$$
\begin{gathered}
1+\varphi^{2}=\sum_{i=1}^{n} \sum_{j=1}^{m} \frac{n_{i j}^{2}}{n_{i} n_{j}}=\frac{8^{2}}{21 * 129}+\frac{64^{2}}{154 * 129}+\cdots \\
+\frac{9^{2}}{135 * 30}=1,0383782 \\
\varphi^{2}=1,039-1=0,039 \text { and } \\
\chi^{2} s t=n * \varphi^{2}=310 * 0,039=12,023
\end{gathered}
$$

As $\chi^{2} s t=12,023>\chi^{2} c r=\chi^{2}(0,05 ; 6)=1,635$, the coefficient $\chi^{2}$ significantly differs from zero with probability of $95 \%$. Correspondingly, there can be observed a tight interrelation between the categorial characteristics.

On the contrary to traditional mathematical and statistical methods of evaluation of respondents' emotional, rational and behavioral responses when buying foodstuffs, a set of neuromarketing tools is more accurate and is based on the study of human nervous system to understand the brain activity states and reveal psychological and emotional responses of interested parties associating with the food industry. 
On having studied various scientific concepts, it was established that neuromarketing is a scientific approach discovering brain responses of separate individuals to marketing stimuli, fixes the information received and synthesizes the results for more intensive stimulation of the emotional component. Nowadays it is one of the most advanced concepts exploring conscious and subconscious responses of the interested parties to neuromarketing stimuli.

Neuromarketing tools have an impact on the interested parties and the society via universal channels of percepting the outer world with involvement of all human senses: audial, visual, tactile, smell and taste perception. Therefore, it is important for food companies to combine the most effective neuromarketing stimuli, that will help a brain to create positive knowledge, impressions and associations regarding foodstuffs from a certain random set of different details. The revealed neuromarketing stimuli of the food industry have been systematized in the motivation model in figure 3 .

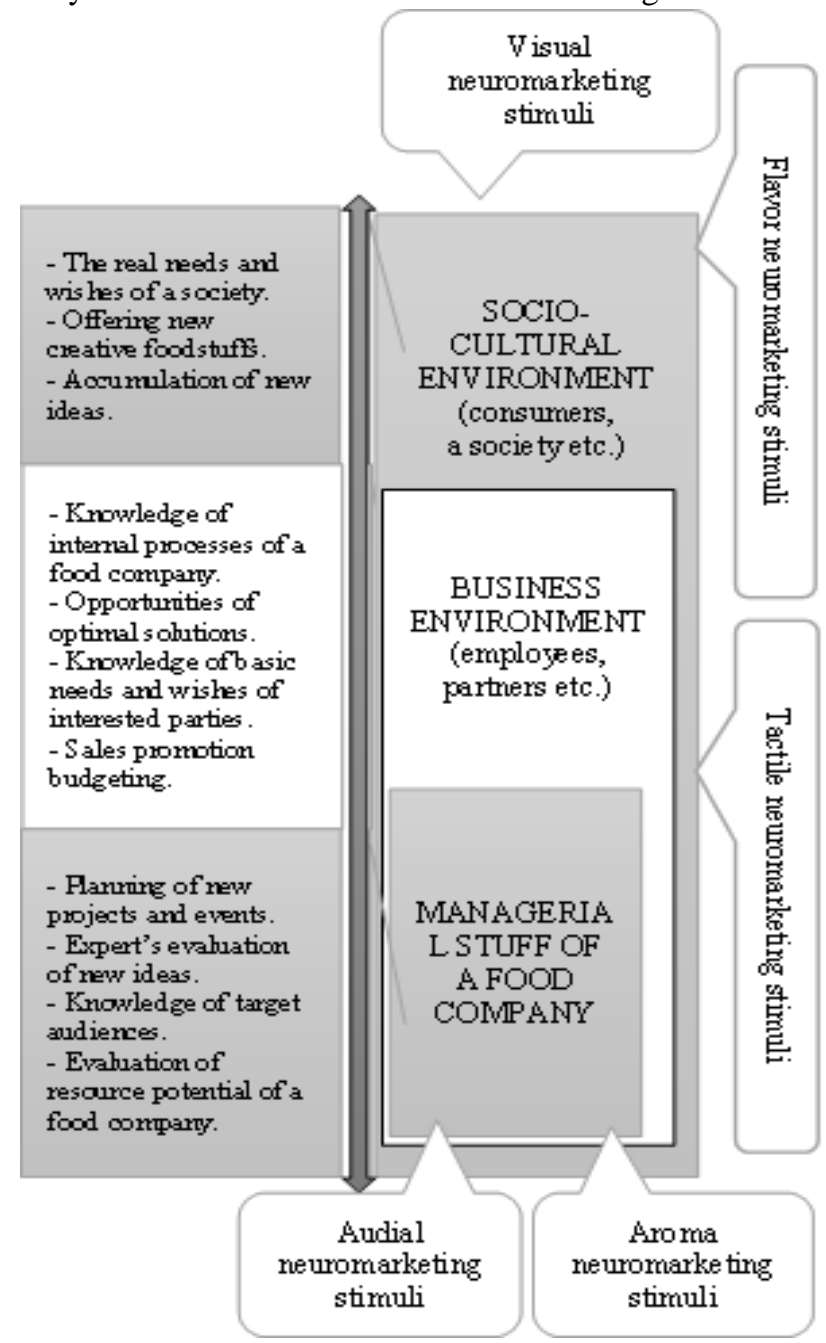

Fig. 3. The motivation model of impact of neuromarketing stimuli on the food industry and society (based on [1])

Audial neuromarketing stimuli create loyalty by sound tools and equipment. Aroma stimuli effect on the brain limbic system and correct the emotional and behavioral response of consumers at food sale points. Flavor neuromarketing stimuli are used at banquets. Tactile stimuli are realized due to the opportunity to touch to foodstuffs at sale points. Visual neuromarketing stimuli increase the effectiveness of video

perception of foodstuffs offered, packaging style, window dressing, product merchandising, content of food company sites etc. Effective application of neuromarketing tools in the food industry and society provides the achievement of simultaneous impact on the five stimuli to receive new ideas from interested parties.

In accordance with the proposed neuromarketing stimuli model of impact on the food industry and society, a company creates a three-level set of actions. The first level is grounded on the social media platform to receive external ideas for quality improvement and creating additional value of foodstuffs. The second level increases the performance of interested parties in the food company (employees, partners etc.). At the third level the managerial stuff reviews external and internal ideas for quality improvement or foodstuff differentiation, examine if projects can really be implemented, provide resources and calculate planned economic efficiency.

The pilot study results regarding potential trends of Ukrainian millennial digitalization are demonstrated on figure 4 .

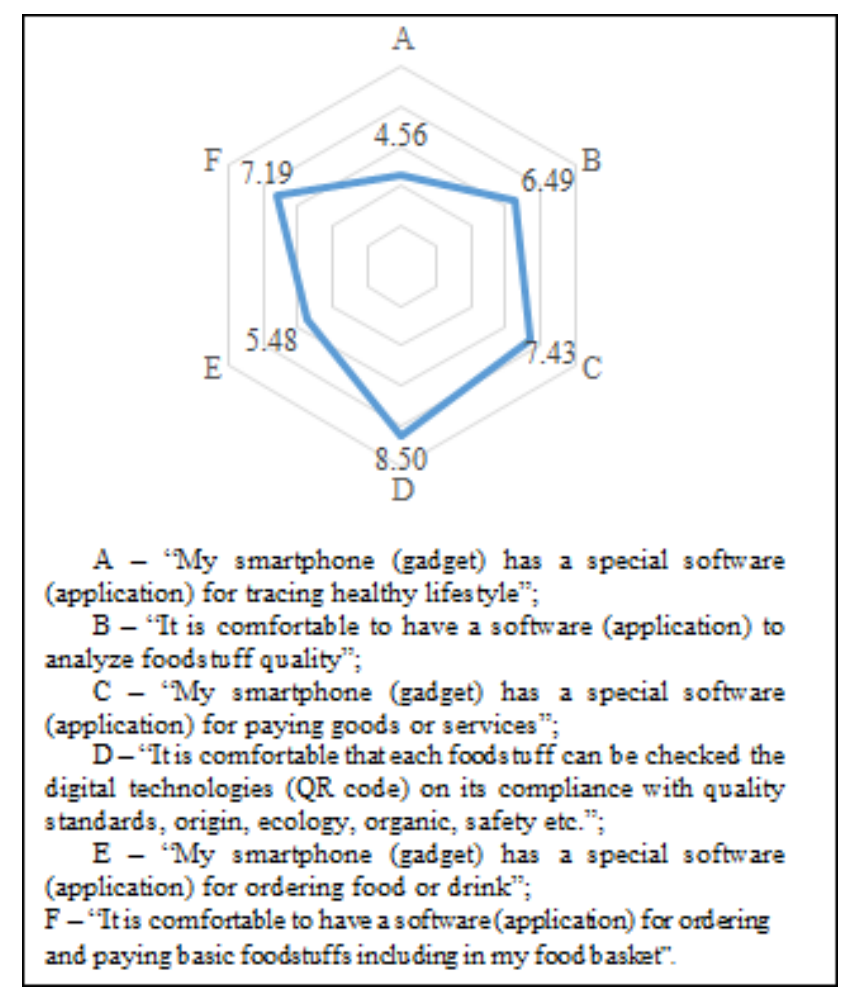

Fig. 4. Trends of Ukrainian millennial digitalization when buying foodstuffs (the pilot study results)

Among the respondence the higher value was received for statement " $D$ " referring to millennials' readiness to effective implementation of digital technologies (including QR code) to get information on characteristics, quality, origin and ecology of foodstuffs (8.5 of 10 points). The lowest value was received for statement " $A$ " referring to actual availability of special software for tracing healthy lifestyle in a smartphone (gadget) (4.56 of 10 points). Thus, millennials' 
attitude to these softwares is almost neutral, though the ones are in great demand, that creates potentials for food companies.

The performed pilot study needs verification of these results at the other level with application of neuromarketing tools, which will help to minimize risks of untrue replies of respondents. The basis of neuromarketing is the study of neurophysiological responses of consumer behavior. "Harvard Business Review" defines a set of neuromarketing tools as measuring physiological and neuron signals to receive an idea of customer motivation, needs, wishes and decisions [8]. In the other words, a set of neuromarketing tools allows to carry out researches of a human brain and its responses in order to effect on the food industry and society [6]; combines neuroscience tools and traditional marketing techniques to form effective strategies of promoting foodstuff's and a company image [2]. The main tools for measuring brain responses to marketing stimuli need additional digitalization and have been systematized in table 2 .

Table 2: the main tools for measuring brain responses to marketing stimuli (based on $[3 ; 4 ; 7]$ )

\begin{tabular}{|c|c|}
\hline $\begin{array}{l}\text { Measuring } \\
\text { tools }\end{array}$ & Characteristics \\
\hline $\begin{array}{c}\text { Fixing of } \\
\text { electrical } \\
\text { rhythmic } \\
\text { activity of } \\
\text { brain neurons }\end{array}$ & $\begin{array}{l}\text { [4] The method of electric } \\
\text { encephalography grounded on fixing } \\
\text { of electrical rhythmic activity of brain } \\
\text { neurons, that is brain waves or } \\
\text { rhythms of the brain activity. The } \\
\text { rhythms of certain amplitude and } \\
\text { frequency correlate with a change in } \\
\text { the human condition and indicate } \\
\text { changes in the level of attention or } \\
\text { emotional state. It enables fixing } \\
\text { transformations which meet the high } \\
\text { speed of information processing by } \\
\text { the brain. }\end{array}$ \\
\hline $\begin{array}{c}\text { Fixing of a } \\
\text { decay of } \\
\text { radionuclides }\end{array}$ & $\begin{array}{l}\text { [7] To measure a response by method } \\
\text { of positron-emission tomography: } \\
\text { Radio farm preparations are injected } \\
\text { into a human body and a decay of } \\
\text { radionuclides monitored by means of } \\
\text { special equipment. }\end{array}$ \\
\hline $\begin{array}{c}\text { Fixing of } \\
\text { skin-galvanic } \\
\text { response }\end{array}$ & $\begin{array}{l}\text { [3] Fixing of skin-galvanic response } \\
\text { or changes in electric resistance of } \\
\text { skin is based on a human's property to } \\
\text { sweat during excitement or feeling } \\
\text { some other strong emotions. The } \\
\text { liquid contains salts of electrolytes, } \\
\text { which increase electrical conductivity } \\
\text { of skin and reduce its resistance. The } \\
\text { above mentioned data are fixed by } \\
\text { devices and interpreted in conclusions } \\
\text { on person's emotional state. }\end{array}$ \\
\hline $\begin{array}{l}\text { Fixing of } \\
\text { cardiovascular } \\
\text { system } \\
\text { parameters }\end{array}$ & $\begin{array}{l}\text { [7] Fixing of cardiovascular system } \\
\text { parameters allows measuring changes } \\
\text { in the heart rate, blood pressure and } \\
\text { blood vessel tone. Analysis of data } \\
\text { makes it possible to make a } \\
\text { conclusion regarding changes in the } \\
\text { level of a person's attention and } \\
\text { emotional state. }\end{array}$ \\
\hline
\end{tabular}

\begin{tabular}{|c|c|}
\hline $\begin{array}{l}\text { Fixing of } \\
\text { activity of } \\
\text { deep brain } \\
\text { structures of } \\
\text { emotional } \\
\text { manifestations }\end{array}$ & $\begin{array}{l}\text { [4] Functional magnetic resonance } \\
\text { tomography provides an opportunity } \\
\text { to trace the character of the activity of } \\
\text { deep brain structures that are } \\
\text { responsible for emotional } \\
\text { manifestations. }\end{array}$ \\
\hline $\begin{array}{c}\text { Fixing eye } \\
\text { movement } \\
\text { reactions }\end{array}$ & $\begin{array}{l}\text { [3] Fixing eye movement reactions by } \\
\text { method of video-fixation of a view } \\
\text { direction, the size of an eye pupil and } \\
\text { the length of an eye retention enables } \\
\text { to define a degree of concentration of } \\
\text { attention on an object, the order of } \\
\text { viewing information (it is especially } \\
\text { important when testing the } \\
\text { convenience of sites, schemes). }\end{array}$ \\
\hline $\begin{array}{c}\text { Fixing of } \\
\text { facial muscles } \\
\text { contraction }\end{array}$ & $\begin{array}{c}\text { [7] Fixing of facial muscles } \\
\text { contraction by means of electric } \\
\text { neuromyograph allows measuring of } \\
\text { emotional response to bioelectric } \\
\text { potentials in muscles during } \\
\text { excitement and analyzes individual } \\
\text { movements of facial mimics that } \\
\text { correspond to a certain emotion or } \\
\text { feeling. }\end{array}$ \\
\hline $\begin{array}{l}\text { Fixing of brain } \\
\text { activity and } \\
\text { speed of } \\
\text { information } \\
\text { processing }\end{array}$ & $\begin{array}{l}\text { [4] The magnet encephalography } \\
\text { method to some extent is identical to } \\
\text { electric encephalography, but is more } \\
\text { innovative and implemented by the } \\
\text { contactless way for monitoring brain } \\
\text { activity and speed of information } \\
\text { processing. }\end{array}$ \\
\hline
\end{tabular}

Thus, neuromarketing tools are a set of specific appliances and methods of neuroscience and psychophysiology (the study of brain, psychophysical responses and human behavioral features) which are used to effect on behavior of interested parties to modify the food industry or society. The prospect of further research is verification of basic hypothesis regarding millennial consumers' rational, emotional and behavioral responses when buying foodstuffs using special equipment and tools.

\section{CONCLUSION}

In the course of the study it has been established that due to society digitalization the Ukrainian millennials gain some different emotional, rational and behavioral responses when choosing and buying foodstuffs. To confirm the basic hypothesis a pilot study of consumer preferences has been carried out among 310 respondents who answered the questions structured into three blocks. The level of conjugation of psychological attitudes to the choice of foodstuffs has been revealed and calculated, as well as the levels of the Ukrainian students' income. The motivational model of effect of neuromarketing stimuli on the food industry and society has been developed. 
Trends of Ukrainian millennial digitalization when buying foodstuffs have been analyzed and prospects of development of neuromarketing tools in the food industry have been defined. It has been concluded that implementation of neuromarketing tools by food companies will contribute to establishing emotional ties with interested parties to understand their conscious and subconscious needs and wishes and create associations for pleasant experience of communication.

Scientific novelty of the study results lays in development of a motivational model of applying neuromarketing stimuli for food companies' effect on a society. This model contains a three-level set of actions and is based on the features of emotional, rational and behavioral responses of millennials when choosing and buying foodstuffs in view of society digitalization.

\section{REFERENCES}

1. Kovshova, I.O. (2018), Marketingovyi menedzhment: teoriia, metodologia, praktika [Marketing Management: Theory, Methodology, Practice], monograph, FOP Vyshymyrskii, Herson, Ukraine, 516 p.

2. Oklander, M. \& Hubareva Y. (2014), Neuromarketing Teoriia ta praktica vplyvu na pidsvidomist spozhyvacha [Neyromarketing - Theory and practice of influencing the consumer's subconscious], Economist, Kyiv, Ukraine, issue 11, pp. 59-62.

3. Ariely, D. \& Berns, G. S. (2010), Neuromarketing The hope and hype of neuroimaging in business, Nature Reviews Neuroscience, 11, pp. 284-292.

4. Banks S. J., Bellerose J., Douglas D., \& Jones-Gotman M. (2012), Bilateral skin conductance responses to emotional faces, Applied psychophysiology and biofeedback 37 (3), pp. 145-152.

5. Dhananjay, M., \& Milind M. (2015), Neuromarketing: Exploring The Brain For Measuring Consumer Behavior, International Journal of Management (IJM), volume 6, issue 3, pp. 16-23.

6. Harrell, Eben (2019), Neuromarketing: What You Need to Know, Harvard Business Review, Special Issue, pp. 64-70.

7. Fortunato, V. C. R., Giraldi, J. D. M. E., \& de Oliveira, J. H. C. (2014), A review of studies on neuromarketing: Practical results, techniques, contributions and limitations, Journal of Consumer Marketing, 24 (7), pp. 385-394.

8. McClure, S. M., Li J. \& Tomlin D. (2004), Neural Correlates of Behavioral Preference for Culturally Familiar Drinks, Neuron, issue 44, pp. 379-387.

\section{AUTHOR PROFILE}

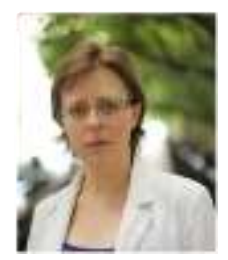

PhD. Zubko Tatyana is the associate Professor at Department of Economics and Finance, Kyiv National University of Trade and Economics, Ukraine. Her research works are focused on theory and practice of consulting management and business modeling, competitiveness and company economic security.

https://orcid.org/0000-0002-8950-1797

zubkotl@gmail.co

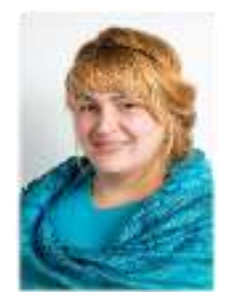

Dr. Iryna Kovshova is the professor at Department of marketing and business management, National University "Kyiv-Mohyla academy", Ukraine. Her research works are focused on theory and practice of marketing management, methodology of making optimal management solutions with application of mathematical models. https://orcid.org/0000-0001-9013-0180 iryna.kovshova@ukma.edu.ua

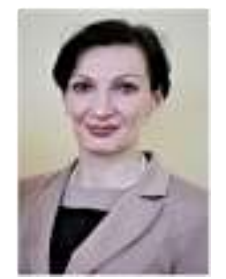

Dr. Oksana Sydorenko is the professor at Department of marketing and business management, National University "Kyiv-Mohyla academy", Ukraine. Her research works are focused on theory and practice of management, emotional intelligence and research methodology.

https://orcid.org/0000-0002-5671-2133

o.sydorenko@ukma.edu.ua 